Copyright (C) 2019 University of Bucharest Printed in Romania. All rights reserved

ISSN print: $1224-5984$

ISSN online: $2248-3942$
Rom Biotechnol Lett. 2019; 24(6): 937-944

doi: $10.25083 / \mathrm{rbl} / 24.6 / 937.944$

Received for publication, September, 2, 2018

Accepted, December, 29, 2018

\title{
Review
}

\section{Anticancer Activity of Natural Bioactive Compounds against Human Carcinoma Cell Lines-A mini review}

\author{
SAHIBZADA SHAKIR REHMAN ${ }^{1}$, AISHA ASHRAF ${ }^{* 2,}$ ZILL-I-HUMA NAZLI ${ }^{2}$, \\ ABIDA KAUSAR ${ }^{2}$, NAILA RAFIQUE ${ }^{3}$, SOFIA PERVEEN ${ }^{3}$, HUMARA NAZ \\ MAJEED $^{3}$, NUSRAT SHAFIQ ${ }^{2}$ \\ ${ }^{1}$ Department of Chemistry, Government Postgraduate College of Science, Faisalabad, (38040), Pakistan \\ ${ }^{2}$ Department of Chemistry, Government College Women University, Faisalabad, (38040), Pakistan \\ ${ }^{3}$ Department of Biochemistry, Government College Women University, Faisalabad, (38040), Pakistan
}

\begin{abstract}
Cancer is one of the most stern health dilemmas engulfing 7 million lives every year globally. It is group of more than 100 diseases. Conventional cancer therapies burdened the disease crippled patient with lethal side effects and are also very expensive. Therefore, the demand to use alternative approaches in treatment of cancer is escalating. Plants of earth are massive reservoir of bioactive compounds. Plant derived compounds such as protoapigenone, casticin, moursin, gypenosides VN5, kalopanaxsaponin A, sapindoside B7, maclekarpine C are foremost anticancer agents, due to their unique structure and sophisticated mechanism of action. The present review is aimed at compiling data on promising classes of bioactive compounds from medicinal plants and their anti cancer mechanism of action against different human carcinoma cell lines.
\end{abstract}

Keywords Alkaloid, Apigenin, Cell lines, Flavonoid, Moursin, Saponin.

To cite this article: REHMAN SS, ZILL-I-HUMA NAZLI AA, KAUSAR A, RAFIQUE N, PERVEEN S, MAJEED HN, SHAFIQ NS. Anticancer Activity of Natural Bioactive Compounds against Human Carcinoma Cell Lines-A mini review. Rom Biotechnol Lett. 2019; 24(6): 937-944. DOI: $10.25083 / \mathrm{rbl} / 24.6 / 937.944$ 


\section{Introduction}

Cancer is atrocious disease. It is second principal motive of mortality worldwide. Cancer is characterized by invasion, apoptotic death, angiogensis, overproliferation of cells, dysregulayion of cell signaling pathways and metastasis (AGGARWAL \& al [1]). Cancer cells may assault tissues which are in close proximity and may broaden through blood flow and lymphatic scheme to other parts of body (NAGARANI \& al [2]). It causes more than six million deaths each year in the world (NISA \& al [3]). Consistent with global cancer statistics issued by the American Cancer Society, daily 20,000 deaths were reported worldwide from cancer, in 2007. By 2050, 27 million new cancer cases and 17.5 million cancer deaths are predicted to crop up in the world [4].

Chief motives of cancer are viruses, environmental exposure (e.g. Ionizing and UV radiations), life style factors (e.g. high fat, low fiber diets, tobacco), medication (e.g. alkylating agents, immunosuppressant) and genetic factors, e.g. inherited mutations, cancer causing genes (MAMBET \& al [5]). Moreover, When production of reactive oxygen species (e.g. superoxide anion radicals, hydroxyl radicals and hydrogen peroxide) is higher in body as compared to enzymetic and non-enzymetic antioxidants (e.g. superoxide dismutase, glutathione peroxidase, ascorbic acid, $\alpha$ - tochopherol, flavonoids, phenolics etc.) then this inequity accompanies cell harm and escort a vast range of degenerative diseases. Thus, reactive oxygen species are one of root of cancer.

Conventional modalities for treatment of cancer such as radiation therapy, chemotherapy, immunodilution and surgery has limited success as evident by high morbidity, toxicity, indiscriminate nature, intense site specificity, permanent disfigurement (NAWAB \& al [6]). These reasons impart a strong momentum to researchers that there is an imperative need of new cancer management.

Plants are earliest associates of mankind. They have been employed for medical issues since 60,000 years ago. 250,000 species of medicinal plants persist on earth, out of which more than one thousand plant species are assessed to have significant anticancer activity (MUKHERJEE \& al [7]), but there is still huge amount of work to be done on these lines. Affirmative effects of plants in anticancer therapy are attributed to profile of bioactive compounds in them.

Although bioactive components of plants include immense array of compounds which might impediment or inhibit the inception of cancer (KOSANIC \& al [8]). But flavonoids, e.g. apigenin, baicalin, genistein, catechin ,saponins e.g. platycodon D, polyphyllin D, Saikosaponin A and Tubeimoside I) and alkaloids e.g. camptothecin, vincristine, vinblastine, berbamine are promising anticancer agents (KOSANIC \& al [8]; CHANG \& al [9]).

Thus keeping in view the anticancer potential of promising classes of bioactive compounds, the present review compiles data on anticancer prospective of latest alkaloids, flavonoids and saponins extracted from terrestrial plants and their mechanism of action against various human carcinoma cell lines.

\section{Flavonoids}

Flavonoids (biflavonids) polyphenolic plant compounds, own a common isoflavones, flavonols, flavanonoes and flavanonols (REN \& al [10]). They are present in flowers, roots, stems, fruits, vegetables, barks, nuts and herbal remedies (GALAT \& al [11]). More than 4000 naturally occurring flavonoids have been reported (KUMAR \& al [12]). They explore anticancer potential by apoptosis induction, anti-angiogenesis (REN \& al [10]), topoisomerase inhibition (CONSTANTINOU \& al [13]), accumulation of p53 (CIOBOTARU \& al [14]), securing DNA from oxidative harm, triggering carcinogen detoxifying system, hindering carcinogen activation cell cycle arrest (LI \& al [15]), improved expression of c-fos and c-myc (CHOI \& al [16]) and inhibition of phosphatidyl-inositol 3-kinase (AGULO \& al [17]). Thus it may be suggested that flavonoids are potential anticancer agents.

Four natural flavoniods casticin, artemetin, quercetagetin and 5, 30-dihydroxy-6,7,40-trimethoxy flavanone have been isolated from Vitex rotundifolia Linne fil. (KOBYAKAWA \& al [18]). Increase in number of cells as a result of growth and reproduction of similar cells by cell division is cause of cancer and is termed as cell proliferation. Antiproliferative activity of casticin in $\mathrm{KB}$ cell lines derived from human squamous cell carcinoma of the oral floor is excellent at low doses as compared to other flavonoids isolated from Vitex rotundifolia Linne fil. DNA histograms from flow cytometric analysis revealed that casticin noticeably arrest cell cycle at G2-M in KB cells. Moreover, immunostaining explored that casticin exhibited marked antimitotic activity by disrupting mitotic spindles in $\mathrm{KB}$ cell lines. Antimitotic activity of paclitaxel and docetaxel in KB cells is also reported (GARCIA \& al [19]).

Many studies have suggested that flavonoids paly a defensive role in averting breast cancer (COORAY \& al [20]). Three natural flavonoids epicatechin, proanthocyanidin B2 and proanthocyanidin B4 have been isolated from Litchi chinensis Sonn. (Litchi) pericarp (ZHAO \& al [21]). Epicatechin, proanthocyanidin B2 and proanthocyanidin B4 are also previously reported from Litchi chinensis Sonn. (ZHAO \& al [22]). Anti-breast cancer activities of Litchi chinensis Sonn. pericarp flavonoids have been evaluated in terms of proliferation of human breast cancer cell line MCF-7 by MTT assay (SUN \& al [23]). Cytotoxic activities of epicatechin and proanthocyanidin B2 are higher in MCF-7 cells than proanthocyanidin B4. Authors also reported that paclitaxel, a refrence anticancer agent, exhibited stronger cytotoxic activities than epicatechin and proanthocyanidin B2.

Protoapigenone, a natural flavonoid isolated from Thelypteris torresiana (Gaud) showed excellent cytotoxic activity in gynecological cancer cells especially MDAH2774 and SKOV3 (ovarian cancer cells) approximated by XTT assay (CHANG \& al [24]). Cytotoxic action of protoapigenone is credited to induction of apoptosis by 
activating caspase- 3 and cleaving the intact PARP. The cleavage of PARP is one of the salient feature of apoptosis and is activated by caspase-3, which is regulated by Bcl-2 family proteins (NICHOLSON \& al [25]). Authors also employed immunohistochemical analysis in protoapigenone treated tumor specimens to notice elevated level of cell death is inappropriate (either too little or too much), then it is motive of various types of cancer. Failure of apoptosis is another cause of cancer .Cytotoxic effect of moursin against HeLa cells may be attributed to fact that moursin induced apoptosis by activating capase-3,8 and 9 proteins and inhibiting nuclear factor $\mathrm{kB}$ signaling (LEE $\&$ al [26]). Induction of apoptosis is also reported by other flavonoids (CONSTANTINOU \& al [27]).

Flavonoids of Teucrium ramosissimum inhibited proliferation of malignant cells at various levels. Apigenin, 4,7-dimethoxy apigenin, cirsimaritin and genkwanin have been reported in T. ramosissimum (SGHAIER \& al [28]) Strongest activity on proliferation of human chronic myelogenous leukemia (K562) cells has been attained with apigenin followed by 4,7-dimethoxy apigenin, cirsimaritin, explored by MTT assay (POLYDORO \& al [29]). Excellent cytotoxicity of apigenin is attributed to presence of hydroxyl group at C-4' and C-7, but presence of methoxy groups at same positions in 4,7-dimethoxy apigenin lessen its cytotoxicity. It is also evident from previous studies that position of hydroxyl group manipulate the confirmation of molecule and alter growth inhibitory consequences (KAWALI \& al [30]). Apigenin is also recently tested on S2-013 and CD18 (human pancreatic cancer) cell lines and proves to be inhibitor of glucose transporter and phosphoinositide 3-kinase/Akt pathway (MELSTROM \& al [31]). Very poor antiprolefertaive activity is scrutinized on human chronic myelogenous K562 cells by genkwanin.

\section{SAPONINS}

Saponis are surface active, non volatile, triterpene or steroid glycosides located in extensive array of plants and certain aquaculture (MAN \& al [32]). They possess wide spectrum of biological and pharmacological properties such as antidiabetic (NORBERG \& al [33]), anti atherosclerotic (ZHANG \& al [34]), hemolytic, molluscidal (SPRAG \& al [35]), anti inflammatory (LI \& al [36]). Anticancer potential of saponins is attributed to inhibition of NF-Kb activation (HUANG \& al [37]), induction of apoptosis in carcinoma cells (TROUILLAS \& al [38]), cell cycle arrest (LIU \& al [39]), inhibition of cell growth and DNA synthesis, mitotic arrest (KAUYEUNG \& al [40]), antiproliferation, transcriptional activation of NSAIDactivated gene (CHEN \& al [41]) and others (KY \& al [42]).

Seven dammarane-type saponins, gypenosides VN1-VN7, are reported from total saponin extract of Gynostemma pentaphyllum aerial parts (XING \& al [43]). Isolated saponins exhibited moderate cytotoxic activity against HL-60 (leukemia), A549 (lung), HT-29 (colon), MCF-7 (breast), and SK-OV-3 (ovary) carcinoma cells.
Cytotoxic effect is assessed by determining metabolic activity using MTT assay. Significant antitumor action of total saponin extract of Gynostemma pentaphyllumis also previously reported. Authors reported that only the $\mathrm{IC}_{50}$ of gypenosides VN5 $\left(\mathrm{IC}_{50}=19.8 \pm 1.0\right)$ against $\mathrm{MCF}-7$ cells is close to reference anticnacer compound, mitoxantrone $\left(\mathrm{IC}_{50}=11.0 \pm 0.8\right)$. Cytotoxic activity of gypenosides is accredited to induction of apotopsis in adenocarcinoma cells. Induction of apoptosis by gypenosides is also previously reported (WNAG \& al [44]). Moreover, the mechanism of apoptosis induced by gypenosides in human colon cancer cells through the mitochondrial dependent pathways and activation of capase- 3 is also on record (CHEN \& al [45]). IC $_{50}$ values also explored that all the seven isolates (Gypenosides VN1-VN7) are weakly active or inactive against all the five carcinoma cell lines.

Three triterpene saponins, androsacin, ardisiacrispin A and saxifragifolin A have been isolated from Androsace integra (DONG \& al [46]). Ardisiacrispin A and saxifragifolin A are also in literature records (WALTHO \& al [47]). Cytotoxicity assay (WANG \& al [48]) of three triterpene saponins against human hepatoma cell line (HepG2) illustrated that ardisiacrispin $\mathrm{A}$ has $\mathrm{IG}_{50}$ of 1.56 $\mu \mathrm{M}$ Pro-apoptotic and microtubule disassembly effects of ardisiacrispin (A plus B) on human hepatoma Bel-7402 cells are previously reported (LIYN \& al [49]).

Three steroidal and two furostanol saponins, named as sarsaparilloside B, sarsaparilloside C, sarsaparilloside, parallin and D20(22)-sarsaparilloside have been detached from roots of Smilax sp. (CHALLINOR \& al [50]). Antiproleferative activity of five saponins against normal fibroblasts and different cancer cell lines have been evaluated. D20(22)-sarsaparillosid from roots of Smilax sp. showed highest cytotoxic effect against breast tumor (MCF-7), melanoma (MM96L) and leukemia (K562) cancer cell lines. Moreover, sarsaparilloside C, of Smilax $s p$. exhibited potent cytotoxic effect against colon tumor (HT29) cancer cell line. D20(22)-sarsaparillosid causes inhibition of cell proliferation by cell lysis as judged by appearance of greatly enlarged cytoplasm. Studies have demonstrated that saponins showed cytotoxicity of cancer cell lines by several mechanisms, such as mitotic inhibition, DNA replication, repair and growth factor signaling, apoptosis, cell lysis and others (CHEUNG \& al [51]; TROUILLAS \& al [52]; MAN \& al [53]).

Three steroidal saponins named as pennogenin-3O- $\alpha$-L-rhamnopyranosyl(1------2)- $\beta$-D-glucopyranoside, pennogenin-3-O- $\alpha$-L-rhamnopyranosyl(1------4)- $\alpha$-Lrhamnopyranosyl (1------4)-[ $\alpha$-L-rhamnopyranosyl(1------$2)$ - $\beta$-D- glucopyranoside and 24- $\alpha$-hydroxyl-pennogenin3-O- $\alpha$-L-rhamnopyranosyl(1-------2)-[ $\alpha$-L-arabinofuranosyl (1------4)]- $\beta$-D-glucopyranoside are isolated from Paris polyphylla Smith var. -yunnanensis (MAN \& al [54]). Antitumor activity of three saponins is elucidated by considering inhibition of growth and proliferation of HepG2 cells in dose dependant and time depandant manner 
and induction of apoptosis. Induction of apoptosis by steriodal saponin, polyphyllin D in drug resistant HepG2 cells is previously reported (CHEUNG \& al [55]). Cell death pattern in HepG2 cells is addressed after treatment with three pennogenin steroidal saponins individually, for $48 \mathrm{~h}$ at $20 \mu \mathrm{M}$ concentration followed by staining with aridine orange and ethidium bromide. Various morphological changes that occur in HepG2 cells are identified by flouresence microscopy. In early stages of apoptosis cell shrinkage and pyknosis may be visualized by light microscopey. Pyknosis is result of chromatin condensation and is characteristic feature of apoptosis. Moreover, nuclear fragmentation, appearance of apoptotic bodies, high permibality of cell membrane and a window for both stained aridine orange and ethidium bromide is also visualized, which is characteristic of apoptosis.

Fourteen triterpene saponins including three new ones, 3 $\beta, 6 \beta, 23$-trihydroxyolean-12oic acid 3-O- $\alpha-\mathrm{L}-$ arabinopyranoside, kalopanaxsaponin L and kalopanaxsaponin $\mathrm{M}$ have been segregated from stem bark of Kalopanax pictus (QUANG\& al [56]). Saponins from leaves of Kalopanax pictus are also in scientific reports. Cytotoxic activity of isolated saponins has been experienced against human cancer cell lines including leukemia (HL-60), colon (HCT-116), and breast (MCF-7), using MTT colormetric method (SCUDIERO \& al [57]). Most potent cytotoxic activity is exhibited by compound sapindoside B7, kalopanaxsaponin A and hederagenin 3-O-a-L-arabinopyranoside against HL-60, HCT-116, and MCF-7 carcinoma cell lines respectively. Cytotoxic activity of the oleanane-type triterpene saponins may be endorsed to free carboxyl group.

Five steroidal saponins have been segregated from Tribulus terrestris (SU \& al [58]). Steroidal saponin from fruits of Tribulus terrestris are also previously reported (WANG \& al [59]). Cytostatic activity of five isolated compounds against leukemia cancer cell lines (HL-60) is evaluated as $\mathrm{IG}_{50}$ values, which stands for inhibition of cell growth by $50 \%$. $\mathrm{IG}_{50}$ values indicated that five saponins of Tribulus terrestris exhibited cytostatic attitude by suppressing cell growth and multiplication.

Two new oleanane triterpenoid saponins, xanthohuskiside $\mathrm{A}$ and xanthohuskiside $\mathrm{B}$ are detached from the husks of Xanthoceras sorbifolia (LI \& al [60]). Growth inhibitory activities of xanthohuskiside A and xanthohuskiside B against human leukemic monocyte lymphoma U937 cell line and human prostate cancer PC-3 cell line are estimated by trypan-blue and MTT methods. Cytotoxic acylated triterpene saponin from the husks of Xanthoceras sorbifolia are already in literature collection (CHAN \& al [61]). Xanthohuskiside B illustrated moderate growth inhibitory activity against human leukemic monocyte lymphoma U937 cell line with $\mathrm{IG}_{50}$ value of $82.85 \pm 1.58 \mu \mathrm{M}$. But xanthohuskiside $\mathrm{B}$ against human prostate cancer PC-3 cell line and xanthohuskiside A against both cell lines are inactive because their $\mathrm{IG}_{50}$ values are more than $100 \mu \mathrm{M}$. Both the xanthohuskiside A and B have glycosidation at $\mathrm{C}-28$ which is pessimistic to anti tumor activity as previously suggested (LI \& al [62]).

\section{Alkaloids}

Alkaloids (nitrogen-containing natural molecules independently of the basic character of the nitrogen) are copious secondary metabolites in plants and stand for one of the most widespread class of compounds endowed with multiple pharmacological properties (STEVIGNY \& al [63]). They explored anticancer activity by inhibiting cell proliferation, inducing cell apoptosis (Programmed cell death characterized by discrete morphological processes) (HUANNG \& al [64]), causing mitotic arrest during cell cycle, exhibiting antineoplastic activity by inhibition of DNA topoisomerase I and triggering mitochondrial pathway of apoptosis which escorts cancer cell death (CHIU \& al [65]).

Five new dihydrobenzophenanthridine alkaloids along with ten known benzophenanthridine/dihydrobenzophenanthridine derivatives and a known amide are isolated from roots of Macleaya microcarpa (DENG \& al [66]). New isolated alkaloids are named as maclekarpine A-E and their cytotoxicity is evaluated against five human carcinoma cell lines incorporating colon (HCT-8), liver (Bel-7402), stomach (BGC-823), ovarian (A2780) and lung (A549) by using MTT assay. IC $_{50}$ values showed that excellent cytotoxicity of maclekarpine A and maclekarpine $\mathrm{D}$ is monitored against BGC-823 cell lines, while that of maclekarpine $\mathrm{C}$ and maclekarpine $\mathrm{E}$ is reported against A2780 and A549 carcinoma cell lines, respectively. Maclekarpine A is active only against human stomach cancer cell line (BGC-823). Maclekarpine B is found inactive against all the tested cell lines. Cytotoxic activity bioassay of known dihydrobenzophenanthridine alkaloids revealed that dihydrochelerythrine and dihydrosanguinarine (ZHANG \& al [67]) methoxilated at C-6 displayed excellent results against $\mathrm{HCT}-8$, A2780 and Bel-7402 cell lines.

Bioassay-guided fractionation of a $\mathrm{CH}_{2} \mathrm{Cl}_{2}$ extract from roots of Nauclea orientalis escorted the isolation of two new isomeric indole alkaloids, named as naucleaorals A and naucleaorals B (SUCHAEM \& al [68]). Indole alkaloids from bark of Nauclea orientalis are also on record (ZHANG \& al [69]). Dimeric indole alkaloids cause disruption of microtubules, dissolution of mitotic spindles and metaphase arrest in dividing cells. Cytotoxicity of naucleaorals A and naucleaorals $\mathrm{B}$ is assessed against $\mathrm{KB}$ (human epidermoid carcinoma) and HeLa (human cervical carcinoma) cell lines by colorimetric method (SICHAEM $\&$ al [70]). In vitro anticancer activity of indole alkaloids in ammonical extracts of Nauclea orientalis is also in literature (ERDELMEIER \& al [71]). Excellent cytotoxic approach is examined by naucleaorals $\mathrm{A}\left(\mathrm{IC}_{50}=4.0 \mu \mathrm{g} / \mathrm{ml}\right)$ against Hela cells, which is close to cytotoxic value of reference anticancer compound, adriamycin $\left(\mathrm{IC}_{50}=0.018 \mu \mathrm{g} / \mathrm{ml}\right)$. 
Naucleaorals B exhibited moderate cytotoxicy against HeLa and KB cells. Naucleaorals A is inactive against KB cells.

Six vobasinyl-ibogan type bisindole alkaloids containing four new ones ervachinines A-D and ten known monoterpeniod indole alkaloids are descripted from the whole plant of Ervatamia chinensis (GUO \& al [72]). Monoterpenoid indole and bisindole alkaloids with antitumor potential are previously reported from genus Ervatamia (HIRASAWA \& al [73]). Cytotoxic attitude of four new bisindole alkaloids ervachinines A-D is monitored against human myeloid leukemia (HL-60), hepatocellular carcinoma (SMMC-7721), lung cancer (A-549), breast cancer (MCF-7), and colon cancer (SW480 cells) cell lines by using MTT method. $\mathrm{IC}_{50}$ values calculated by Reed and Muech's method explored that ervachinines $\mathrm{A}$ and ervachinines $\mathrm{C}$ exhibited better inhibitory activities than reference anticancer compound cisplastin, against all five cell lines. Cytotoxicity of ervachinines $\mathrm{C}$ is superior than that of ervachinines D against HL-60, SMMC-7721 and MCF-7 cells. Bisindole alkaloids interact with tubulin, dimeric cellular protein and cellular metabolic functions resulting in mitotic arrest and cell crenelation. Ervachinine E is recently reported from Ervatamia chinensis (GUO \& al [74]) and modest cytotoxicity by it is explored against human myeloid leukemia (HL-60), hepatocellular carcinoma (SMMC7721), lung cancer (A-549), breast cancer (MCF-7) and colon cancer (SW480) cells.

One aporphine alkaloide and nine other compounds are isolated from flowers of Goniothalamus laoticus (LEKPHROM \& al [75]). Cytotoxicity of aporphine alkaloide, nordicentrine, is evaluated against human epidermoid carcinoma (KB), human breast cancer (BC1 and MCF-7) and human small cell lung cancer (NCI-H187) cell lines employing the colorimetric method. Nordicentrine, exhibited excellent cytotoxicities agaisnt KB and NCI-H187 cells. This is in accordance with results of who showed excellent cytotoxic activities against twelve cancer cell lines. Moreover, cytotoxicities of nordicentrine against KB and NCI-H187 cells are close to cytotoxic values of doxorubicin and ellipticine, used as reference anticancer agents. Cytotoxic assay indicated that nordicentrine showed very strong activity against human epidermoid carcinoma and human small cell lung cancer cell lines. Good cytotoxic activity is observed by nordicentrine against MCF-7 cells, while activity of nordicentrine against human breast cancer cell lines is not determined.

Table. Anticancer mechanism of action of bioactive compounds

\begin{tabular}{|c|c|c|c|}
\hline Compound & Mechanism of Action & $\begin{array}{c}\text { Human Cancer } \\
\text { Cell Line }\end{array}$ & Reference \\
\hline Protoapigenone & $\begin{array}{l}\text { Induction of apoptosis by } \\
\text { activating caspase- } 3 \text { and } \\
\text { cleaving the intact PARP }\end{array}$ & $\begin{array}{l}\text { MDAH-2774 } \\
\text { SKOV3 } \\
\text { HeLa } \\
\text { C33A } \\
468 \\
\text { T47D }\end{array}$ & {$[24]$} \\
\hline Apigenin & Antiproleferative action & K562 & {$[33]$} \\
\hline Moursin & $\begin{array}{l}\text { Induction of apoptosis by } \\
\text { activating capase- } 3,8 \text { and } \\
9 \text { proteins \& Inhibition of } \\
\text { nuclear factor kB signaling }\end{array}$ & $\begin{array}{l}\text { HeLa } \\
\text { MCF-7 } \\
\text { Hep3B }\end{array}$ & [33] \\
\hline D20(22)-sarsaparillosid & $\begin{array}{l}\text { Inhibition of cell proliferation by } \\
\text { cell lysis }\end{array}$ & $\begin{array}{l}\text { MCF-7 } \\
\text { MM96L } \\
\text { K562 }\end{array}$ & {$[54]$} \\
\hline Gypenosides VN5 & Induction of apoposis & $\begin{array}{l}\text { HL-60 } \\
\text { MCF-7 } \\
\text { HT-29 } \\
\text { A-549 } \\
\text { SKOV-3 }\end{array}$ & [47] \\
\hline Ervachinines A-D & $\begin{array}{l}\text { Mitotic arrest } \\
\text { Cell crenelation }\end{array}$ & $\begin{array}{l}\text { MCF-7 } \\
\text { HL-60 } \\
\text { A-549 } \\
\text { SMMC-7721 } \\
\text { SW480 }\end{array}$ & [76] \\
\hline
\end{tabular}

\section{Conclusion}

Plants are pipeline of biologically active and miscellaneous anticancer agents. Although a range of plants is screened for anticancer potential, but lot of work is to be done on these lines. In this article, we reviewed some plant based active compound having potential against vast range of human carcinoma cell lines, which will be used in future for development of drugs exclusive of any adverse effects. 


\section{References}

1. B.B. AGGARWAL, G. SETHI, K.S. AHN, S.K. SANDUR, K.S. PANDEY, A.B. KUNNUMAKKARA, B. SUNG, H. ICHIKAWA. Targeting signal-transducer-and-activator-of-transcription-3 for prevention and therapy of cancer: modern target but ancient solution, Ann. N.Y. Acad. Sci, 1091: 151-169 (2006).

2. B. NAGARANI, S.D. NATH, S. KUMAR, C. CHIRANJIB, G. BHATTACHARJEE, G. KUMAR. A review: herbs used as anticancer agents. Inter Res J Pharm, 2: 20-24 (2011).

3. S. NISA, Y. BIBI, A. WAHEED, M. ZIA, S. SARWAR, S. AHMED, M.F. CHAUDARY. Evaluation of anticancer activity of Debregeasia Salicifoliae extract against estrogen receptor positive cell line. Afr. J. Biotechnol, 10: 990-995 (2011).

4. American Cancer Society. Cancer Prevention \& Early Detection Facts \& Figures. Atlanta, GA. (2007).

5. C. MAMBET, L.G. NECULA, A.I. NEAGU, I. ALDEA, L. MATEI, D. DRAGU, M. LIVADARIU, M. ECONOMESCU, C. BLEOTU, D. ION, C.C. DIACONU. HOX genes, reviewing the molecular bridges between developmental anomlies and cancer. Rom. Biotechnol. Lett, 20: 10504-10511.

6. A. NAWAB, M. YUNUS, A.A. MEHDI, S. GUPTA. Evaluation of anticancer properties of medicinal plants from Indian sub continent. Mol. Cell. Pharmacol, 3: 21-29 (2011).

7. A.K. MUKHERJEE, S. BASU, N. SARKAR, A.C. GOSH. Advances in cancer therapy with based natural products. Curr. Med. Chem, 8: 1467-1486 (2011).

8. M. KOSANIC, B. RANKOVIC, T. STANOJKOVIC. Evaluation of antioxidant, antimicrobial and anticancer effects of three selected marine macroalgae. Rom. Biotechnol. Lett, 24: 1380-13813.

9. H.L. CHANG, J.H. SU, Y.T. YEH, Y.C. LEE, H.M. CHEN, Y.C. WU, S.S.F. YUAN. Protoapigenone a novel flavonoid inhibits ovarian cancer cell growth in vitro and in vivo. Canc Letters, 267: 85-95 (2008).

10. W. REN, Z. QIAO, H. WANG, L. ZHU, L. ZHANG. Flavonoids: promising anticancer agents. Med. Res. Rev, 23: 519-534 (2003).

11. G. GALAT, P.J.O. BRIEN. Potential toxicity of flavonoids and other dietry phenolics: significance for their chemo preventive and anticancer properties. Fre Radi. Biol. Med, 37: 287-303 (2004).

12. S. KUMAR, A.K. PANDEY. Chemistry and biological activities of flavonoids:an overview. The Sci. World. J, 2013:1-16 (2013).

13. A.I. CONSTANTINOU, N. KAMATH, J.S. MURLEY. Genistein inactivates bcl-2, delays the G2/M phase of the cell cycle, and induces apoptosis of human breast adenocarcinoma MCF-7 cells. Europ. J. Can, 34: 1927-1934 (1998).

14. O.R. CIOBOTARU, D.C. VOINESCU, O.C. CIOBOTARU, D. VOICU, M. ARBUNE. Expression of p53 and Ki-67 in distal oesophageal and gastric cardis adenocarcinomas. Rom Biotechnol. Lett, 20: 10800-10808 (2015).

15. J.Y. LI , W. CHENG, W. QU, Y. SUN, Z. WANG, H. WANG, B. TIAN. Fisetin, a dietary flavonoid, induces cell cycle arrest and apoptosis through activation of p53 and inhibition of NF-kappa B pathways in bladder cancer cells. Bas. Clinic. Pharmac. Toxicol, 108: 84-93 (2011).

16. S.K. CHOI, Y.J. SON, J.M. YUN, S.H. KIM. Fisetin inhibits osteoclast differentiation via downregulation of p38 and c-Fos-NFATc1 signaling pathways. Evidence-Based Compl Altern Med, 9: 2012 (2012).

17. G. AGULLO, L. GAMET-PAYRASTRE, S. MANENTI, C. VIALA, C. REMESY, H. CHAP, B. PAYRASTRE. Relationship between flavonoid structure and inhibition of phosphatidylinositol 3-kinase: a comparison with tyrosine kinase and protein kinase $\mathrm{C}$ inhibition. Biochem Pharmacol, 53: 1649-1657 (1997).

18. J. KOBAYAKAWA, F.S. NISHIMORI, M. MORIYASU, Y. MATSUKAWA. G2-M arrest and antimitotic activity mediated by casticin, a flavonoid isolated from Viticis Fructus (Vitex rotundifolia Linne fil.). Can. Lett, 208: 59-64 (2004).

19. P.D. GARCIA, G. BRAGUER, S.E. CARLES, Y. KHYARI, Y. BARRA, C. INES, I. BARASOIAN, C. BRIAND. Comparative effects of taxol and Taxotere on two different human carcinoma cell lines. Can. Chem. Pharmacol, 34: 335-343.

20. H.C. COORAY, T. JANVILISRI, H.W.V. VEEN, S.B. HLADKY, M.A. BARRAND. Interaction of the breast cancer resistance protein with plant polyphenols. Biochem. Biophy. Res. Comm, 317: 269275 (2004).

21. M.M. ZHAO, B. YANG, J.S. WANG, B.Z. LI, Y.M.JIANG. Identification of major flavonoids from pericarp tissues of lychee fruit in relation to their antioxidant acrivities. Food Chem, 98: 539-544 (2006).

22. M. ZHAO, B. YANG, J. WANG, Y. LIU, L. YU, Y. JIANG. Immunomodulatory and anticancer activities of flavonoids extracted from litchi (Litchi chinensis Sonn.) pericarp. Intern. Immunopharm, 7:162-166 (2007)S.

23. H.X. SUN, F. QIN, Y.J. PAN. In vitro and in vivo immunosuppressive activity of Spica prunellae ethanol extract on the immune responses in mice. J Ethnopharm, 101: 31-36 (2005).

24. H.L. CHANG, J.H. SU, Y.T. YEH, Y.C. LEE, H.M. CHEN, Y.C. WU, S.S.F.YUAN. Protoapigenone a novel flavonoid inhibits ovarian cancer cell growth in vitro and in vivo. Canc Letters, 267: 85-95 (2008).

25. D.W. NICHOLSON, N.A. THORNBERRY. Caspases: killer proteases. Trends Biochem. Sci, 22: 299-306 (1997).

26. S.Y. LEE, G.T. KIM, S.H. ROH, J.S. SONG, H.J. KIM, S.S. HONG, S.W. KWON, J.H. PARK. Proteomic analysis of the anti-cancer effect of 
20S-Ginsenoside $\operatorname{Rg}(3)$ in human colon cancer cell lines. Bioscience, Biotech. Biochem, 73: 811-816 (2009).

27. A.I. CONSTANTINOU, N. KAMATH, J.S. MURLEY Genistein inactivates bcl-2, delays the G2/M phase of the cell cycle, and induces apoptosis of human breast adenocarcinoma MCF-7 cells. Europ. J. Can, 34: 1927-1934 (1998).

28. M.B. SGHAIER, I. SKANDRANI, N. NASR, M.G.D. FRANCA, L.C. GHEDIRA, K. GHEDIRA. Flavonoids and sesquiterpenes from Tecurium ramosissimum promote antiproliferation of human cancer cells and enhance antioxidant activity: A structure-activity relationship study. Enviro. Toxicol. Pharmacol, 32: 336-348 (2011)

29. M. POLYDORO, K.C.B. DE SOUZA, M.E. ANDRADES, E.G. DA SILVA, F. BONATTO, J. HEYDRICH. Antioxidant, a prooxidant and cytotoxic effects of Achyrocline satureioides extracts Brazil. Life. Sci, 74: 2815-2826 (2004).

30. S. KAWAII, Y. TOMONO, E. KATASE, K. OGAWA, M. YANO. Effect of Citrus flavonoids on HL-60 cell differentiation. Antican. Res, 19: 1261-1270 (1999).

31. L.G. MELSTROM, M.R. SALABAT, X.Z. DING, B.M. MILAM, M. STROUCH, J.C. PELLING, D.J. BENTREM. Apigenin inhibits the GLUT-1 glucose transporter and the phosphoinositide 3-kinase/Akt pathway in human pancreatic cancer cells. Pancreas, 37: 426-431 (2008).

32. S.L. MAN, W.Y. GAO, Y.J. ZHANG,L.L. YAN, C.Y. MA, C.X. LIU, L.Q. HUANG. Antitumor and antimetastatic activities of Rhizoma Paridis saponins. Steroids, 74: 1051-1056 (2009).

33. A. NORBERG, N.K. HOA, E. LIEPINSH, D.V. PHAN, N.D. THUAN,H. JORNVALL, R. SILLARD, C.G. OSTENSON. A novel insulin-releasing substance, phanoside, from the plant Gynostemma pentaphyllum. J. Biol. Chem, 279: 41361-4136 (2004).

34. Y.G. ZHANG, H.G. ZHANG, G.Y. ZHANG, J.S. FAN, X.H. LI, Y.H. LIU, S.H. LI, X.M. LIAN, Z. TANG. Panax notoginseng saponins attenuate atherosclerosis in rats by regulating the blood lipid profile and an anti-inflammatory action. Clini. Exper. Pharm. Physiol, 35: 1238-12444 (2008).

35. S.G. SPARG, M.E. LIGHT, J.V. STADEN. Biological activities and distribution of plant saponins. J. Ethnopharm, 94: 219-243 (2004).

36. Y.N. LI, Y.L. WU, Z.H. JIA, J.S. QI. Interaction between COX-2 and iNOS aggravates vascular lesion and antagonistic effect of ginsenoside. J. Ethnopharm, 119: 305-311 (2004).

37. Y. HUANG, Y. FANG, J. WU, J.M. DZIADYK, X. ZHU, M. SUI, W. FAN. Regulation of Vinca alkaloid-induced apoptosis by NF-kappaB/IkappaB pathway in human tumor cells. Mole. Can. Therap, 3: 271-277 (2004).

38. P. TROUILLAS, C. CORBIERE, B. LIAGRE, J.L. DUROUX, J.L. BENEYTOUT. Structure-function relationship for saponin effects on cell cycle arrest and apoptosis in the human 1547 osteosarcoma cells: a molecular modelling approach of natural molecules structurally close to diosgenin. Bioorg. Med. Chem, 13: 1141-1149 (2005).

39. M.J. LIU, Z. WANG, Y. JU, J.B. ZHOU, Y. WANG, R.N. WONG. The mitotic-arresting and apoptosisinducing effects of diosgenyl saponins on human leukemia cell lines. Biol. Pharm. Bulletin, 27: 10591065 (2004).

40. K.K AUYEUNG, C.H. CHO, J.K. KO. A novel anticancer effect of Astragalus saponins: Transcriptional activation of NSAID-activated gene. Int. J. Cancer, 125: 1082-1091 (2009).

41. J.C. CHEN, K.W. LU, J.H. LEE, C.C. YEH, J.G. CHUNG. Gypenosides induced apoptosis in human colon cancer cells through the mitochondria-dependent pathways and activation of caspase-3. Antican. Res, 26: 4313-4326 (2006).

42. P.T. KY, P.T. HUONG, T.L.V. HIEN. Tumor inhibitory effects of total saponin extract of Gynostemma pentaphyllum (Thunb.) Makino. Viet. J. Pharm. Med. Inform. 11: 36-38 (2007)

43. S.F. XING, M. JANG, Y.R. WANG, X.L. PIAO. A new dammarane type saponin from Gynostemma pentaphyllum induces apoptosis in A549 human lung carcinoma cells. Bioorg. Med. Chem. Lett, 26: 17541759 (2016).

44. Q.F. WANG, C.W. CHIANG, C.C. WU, C.C. CHENG, S.J. HSIEH, J.C. CHEN, Y.C. HSIEH, S.L. HSU. Gypenosides induce apoptosis in human hepatoma Huh-7 cells through a calcium/reactive oxygen species-dependent mitochondrial pathway. Plant. Med, 73: 535-544 (2007).

45. J.C. CHEN, K.W. LU, J.H. LEE, C.C. YEH, J.G. CHUNG. Gypenosides induced apoptosis in human colon cancer cells through the mitochondria-dependent pathways and activation of caspase-3. Antican. Res, 26: 4313-4326 (2006).

46. W. DONG, X. LIU, X. LI,D. YANG, L. DING. A new triterpene saponin from Androsace integra. Fitoterap, 82: 782-785 (2011).

47. WALTHO JP, WILLIAMS DH, MAHATO SB, PAL BC, BARNA JC. Structure elucidation of two triterpenoid tetrasaccharides from Androsace saxifragifolia. J. Chem. Soc. Perkin. Trans. 1, 15271531 (1981).

48. Q.F. WANG, C.W. CHIANG, C.C. WU, C.C. CHENG, S.J. HSIEH, J.C. CHEN, Y.C. HSIEH, S.L. HSU. Gypenosides induce apoptosis in human hepatoma Huh-7 cells through a calcium/reactive oxygen species-dependent mitochondrial pathway. Planta Med, 73: 535-544 (2007).

49. Y.N. LI YN, WU, YL, JIA ZH, QI JS. Interaction between COX-2 and iNOS aggravates vascular lesion and antagonistic effect of ginsenoside. J. Ethnopharm, 119: 305-311 (2008).

50. V.L. CHALLINOR, P.G. PARSONS, S. CHAP, E.F. WHITE, J.T. BLANCHFIELD, R.P. LEHMANN, J.J.D. VOSS. Steroidal saponins from the roots of Smilax sp. structure and bioactivity. Steroids, 77: 504-511 (2012). 
51. J.Y.N. CHEUNG, R.C.Y. ONG, Y.K. SUEN, V. OOI, H.N.C. WONG, T.C.W. MAK, K.P. FUNG, B. YU, S.K. KONG. Polyphyllin D is a potent apoptosis inducer in drug-resistant HepG2 cell. Canc. Lette, 217: 203-211 (2005).

52. P. TROUILlaS, C. CORBIERE, B. LIAGRE, J.L. DUROUX, J.L. BENEYTOUT. Structurefunction relationship for saponin effects on cell cycle arrest and apoptosis in the human 1547 osteosarcoma cells: a molecular modelling approach of natural molecules structurally close to diosgenin. Bioorg. Med. Chem, 13:1141-1149 (2015).

53. S.L. MAN, W.Y. GAO, Y.J. ZHANG, L.L. YAN, C.L. MA, C.X. LIU, L.Q. HUANG. Antitumor and antimetastatic activities of Rhizoma Paridis saponins. Steroids, 74:1051-1056 (2009).

54. L.J. ZHU, B. TAN, WANG, L. GUAN,Y. LIU, C. ZHENG. In-vitro antitumor activity and antifungal activity of Pennogenin steroidal saponins from paris Polyphylla var. yunnanensis. Iran. J. Pharma. Res, 10: 279-286 (2011).

55. J.Y.N. CHEUNG, R.C.Y. ONG, Y.K. SUEN, V. OOI, H.N.C. WONG, T.C.W. MAK, K.P. FUNG, B. YU, S.K. KONG. Polyphyllin D is a potent apoptosis inducer in drug-resistant HepG2 cell. Can. Lett, 217: 203-211 (2005).

56. T.H. QUANG, N.T.T. NGAN, C.V. MINH, P.V. KIEM, H.J. BOO, J.W. HYUN, H.K. KANG, Y.H. KIM. Cytotoxic triterpene saponins from the stem bark of Kalopanax pictus. Phytochem. Lett, 5:177-182 (2012).

57. D.A. SCUDIERO, R.H. SHOEMAKER, K.D. PAULL, A. MONKS, S. TIERNEY, T.H. NOFZIGER, M.J. CURRENS, D. SENIFF, M.R. BOYD MR. Evaluation of a soluble tetrazolium/ formazan assay for cell growth and drug sensitivity in culture using human and other tumor cell lines. Can. Res, 48: 4827-4833 (1988).

58. L. SU, G. CHEN, S.G. FENG, W. WANG, Z.F. LI, H. CHEN, X.X. LIU, Y.H. PEI. Steroidal saponins from Tribulus terrestris. Steroid, 74: 399-403 (2009).

59. Q.F. WANG, C.W. CHIANG, C.C. WU, C.C. CHENG, S.J. HSIEH, J.C. CHEN, Y.C. HSIEH, S.L. HSU. Gypenosides induce apoptosis in human hepatoma Huh-7 cells through a calcium/reactive oxygen species-dependent mitochondrial pathway. Planta. Med, 73: 535-544 (2007).

60. Z.L. LI, D.Y. LI, X.M. HE, H.M. HUA. Two new triterpenoid saponins from the husks of Xanthoceras sorbifolia. Nat. Prod. Res, 1-6 (2012).

61. P.K. CHAN,M. ZHAO, C.T. CHE, E. MAK. Cytotoxic acylated triterpene saponins from the husks of Xanthoceras sorbifolia. J. Nat. Prod, 71: 12471250 (2008).

62. Z.L. LI, X. LI, D.Y. LI, D.L. MENG, W. LI, Y. SHA. Triterpenoid prosapogenols and prosapogenins from the husks of Xanthoceras sorbifolia. J. Asi. Nat. Prod. Res, 9: 387-392 (2007).
63. C. STEVIGNY, C. BAILLY, J.Q. LECLERCQ. Cytotoxic and antitumor potentialities of Aporphinoid alkaloids. Curr. Med. Chem. Anti-Cancer. Agent, 5: 173-182 (2005).

64. Y. HUANNG, Y. FANG, J. WU, J.M. DZIADYK, X. ZHU, M. SUI, W. FAN. Regulation of vinca alkaloid induced apoptosis by NF-kappaB pathway in human tumor cells. Mol. Canc. Ther, 3:271-277 (2004).

65. W.H. CHIU, S.J. LUO, C.L. CHEN, J.H. CHENG, C.Y. HSIEH, C.Y. WANG, W.C. HUANG, W.C. SU, C.F. Lin. Vinca alkaloids cause aberrant ROSmediated JNK activation, Mcl-1 downregulation, DNA damage, mitochondrial dysfunction, and apoptosis in lung adenocarcinoma cells. Biochem. Pharmacol, 83:1159-1171 (2012).

66. A.J. DENG, H.L. QIN. Cytotoxic dihydrobenzophenanthridine alkaloids from the roots of Macleaya microcarpa. Phytochem, 71: 816-822 (2010).

67. G.L. ZHANG, G. RUCKER, E. BREITMAIER, R. MAYER. Alkaloids from Hypecoum leptocarpum. Phytochem, 40: 1813-1816 (1995).

68. J. SICHAEM, S. SURAPINIT, P. SIRIPONG, S. KHUMKRATOK, J. JONG-ARAMRUANG, S. TIP-PYANG. Two new cytotoxic isomeric indole alkaloids from the roots of Nauclea orientalis. Fitot, 81: 830-833 (2010).

69. Y.G. ZHANG, H.G. ZHANG, G.Y. ZHANG, J.S. FAN, X.H. LI, Y.H. LIU, S.H. LI, X.M. LIAN, Z. TANG. Panax notoginseng saponins attenuate atherosclerosis in rats by regulating the blood lipid profile and an anti-inflammatory action. Clinical Exp. Pharmacol. Physiol, 35:1238-12444.

70. J. SICHAEM, S. SURAPINIT, P. SIRIPONG, S. KHUMKRATOK, J. JONG-ARAMRUANG, S. TIP-PYANG. Two new cytotoxic isomeric indole alkaloids from the roots of Nauclea orientalis. Fitoter, 81: 830-833 (2010).

71. C.A.J. ERDELMEIER, U. REGENASS, T. RALI, O. STICHER. Indole alkaloids with in vitro antiproliferative activity from the ammoniacal extract of Nauclea orientalis. Planta Med, 58: 43-48 (2012).

72. L.L. GUO, Y. ZHANG, H.P. HE, Y. LI, J.P. YU, X.J. A new monoterpenoid indole alkaloid from Ervatamia chinensi. Chin. J. Nat. Med. 10: 226-229 (2012).

73. Y. HIRASAWA, S. MIYAMA, T. HOSOYA, K. KOYAMA,A. RAHMAN, I. KUSUMAWATI, N.C. ZAINI NC, H. MORITA, A.A. ALASMONTAMINE, first tetrakis monoterpene indole alkaloid from Tabernaemontana elegans. Org. Lett. 11: 5718-5721 (2014).

74. L.L. GUO, H.P. HE, Y.T. DI, S.F. LI, Y.Y. CHENG, W. YANG, Y. LI, J.P. YU, Y. ZHANG, X.J. HAO. Indole alkaloids from Ervatamia chinensis. Phytochem, 74: 140-145 (2012).

75. R. LEKPHROM, S. KANOKMEDHAKUL, K. KANOKMEDHAKUL. Bioactive styryllactones and alkaloid from flowers of Goniothalamus laoticus. J. Ethnopharm, 125: 47-50 (2009). 